\title{
Study on surface water resources (river and pond) and their effects on agriculture at Godagari area, Rajshahi
}

\begin{abstract}
An attempt was made to study the surface water level of Padma and Mahananda river. We also studied about the discharge rate of Padma and Mahananda river. In peak season the water level and discharge for both river was higher than off peak season. So the water is stored in the peak season for the purpose of irrigation in dry season. The fluctuation of water level and discharge of Padma river is much more than the Mahanada river. An attempt was made to study the surface water irrigation system by burind Multipurpose Development Authority [BMDA]. The research was carried out on farm level at different places around Rajarampur pond shantospur pond. The complete work was carried out on various fields like water Level Discharge, Agricultural crop analysis, Environmental variation and analysis. A large area more than 500 acre has been made possible to cultivate only after the installation of the project in the dry season. As a result the annual production of various crops such as Aus, Amon, Boro, Wheat, Potato, Gram, Rape and Mustard, etc. Has increased to a large amount. The use of surface water from Rajarampur pond and Shantospur pond site has increased the production rate to $0.6 \mathrm{M}$.Ton to $1.2 \mathrm{M}$.Tons per hectare. It has been possible to plant lots of different types of trees in pond region which helps to keep the nature in normal condition. On the other hand the use of deep tube well for extracting ground water for the irrigation purposes is leading the ground water depletion and also may lead to natural imbalance. From a manual calculation it is found that about 4000 liters of water is required to produce to produce $1 \mathrm{~kg}$ of rice. So the concern should be made on using the surface water to meet the huge irrigation demand.
\end{abstract}

Keywords: irrigation, water level discharge, agricultural crops, extracting ground water
Volume 3 Issue 2 - 2019

\author{
Md Razibur Rahman, Md Mamun Hossain, \\ Md Shariful Islam \\ Department of civil Engineering, RUET, Bangladesh
}

Correspondence: Shariful Islam, Department of civil Engineering, RUET, Bangladesh, Email sharif.ruet12@gmail.com

Received: January 18, 2019 | Published: March 14, 2019

\section{Introduction}

Bangladesh occupies the lower deltaic region at the confluence of Padma, Brahmaputra, Meghna river and major part of the basins of Karnafuli, Sangu and Matamuhuri rivers in the Chittagong hilly region. Except at the Chittagong hills where hill tops attend elevation above two thousand sea level, $90 \%$ of the deltaic area is more or less plain. The area of Bangladesh is about one lakh forty five thousand acquire kilometers of which approximately one lakh two thousand square kilometers are cultivable land. The tropic of cancer passes approximately through the center of Bangladesh, but its climate is tropical in part of the year and sub- tropical during the other part of the year. In the monsoon season, from mid-June to mid-October, the weather is what and humid and about $75 \%$ of annual average rainfall occurs in this period. Md. Mezanur Rahman \& Md Shihab Uddin, ${ }^{1}$ Study on Shormongla Canal and its impact on Ground water, Agriculture and Environment ",supervised by Prof. Dr. Shafi Uddin Miah ,department of Civil Engineering, RUET, angladesh. The objective of the study was to study rainfall, water resources of the projected area.Since Rainfall quantity is less so surface water of Padma river was stored in Shormongla canal. The stored water was used in dry season for irrigation purpose. In Godagari zone the amount of rainfall is less and temperature is high .The irrigated land is too hard to cultivate. The weather condition is too tough. The ground water level is going downward continuously. The demand of water is too much high because rice is cultivated in all season. The economic condition of the farmer is so poor. So in dry season the irrigation becomes too much impossible. In 2012 after starting the government administration to overcome extreme drought condition ,re-excavation of Rajarampur pond and Shantospur pond has been started for reserving the surface possessions of land.The project was implemented by BMDA (Burind Multipurpose Development Authority) funded by the SEMP (Sustainable Environment Program of UNDP (United Nations Development Program) under the Ministry of Agriculture .After re-excavation the pond is introduced as the largest water reservoir of that area.

From the agricultural point of view, the growing season is all the year around. The Padma river, which rises in Nepal and passes through India and then enters Bangladesh, is the main source of water for irrigation for North- West part of the country mainly Rajshahi region. Godagari Upazilla at Rajshahi District. This area displays the typical type alluvial plain of the delta in the East and South and the hill is called Burind tract in the West. The alluvial plain is about $12 \mathrm{~m}$ or $40 \mathrm{ft}$ above the mean sea level, whereas Burind Tract being between $12-45 \mathrm{~m}$ or 40-130ft. Expected beneficiary nos. of farmer family of this area is about 5324 and the total target area is 1000 ha and the total amount of crop yield per year is $10000 \mathrm{mt}$ of the study area. It has 40011 units of house hold and total area $472.13 \mathrm{~km}^{2}$.As of the 1991 Bangladesh census Godagari has a population of 217811. Males constitute are $50.88 \%$ of the population, and females $49.12 \%$. This Upazilla's eighteen up population is 108869 . Gadaguri has an average literacy rate of $27.6 \%(7+$ years $)$, and the national average of $34 \%$ literate. Density of population is 461 per $\mathrm{km}^{2}(1190$ per sq. mile) in 
Godagari. Main occupations agriculture 36.36\%, agricultural laborers $32.16 \%$, wage laborers $5.35 \%$, commerce $11.25 \%$, service $3.99 \%$ and others $10.89 \%$. Land use total cultivable land 35750.71 hectares; fallow land 218.74 hectares; single crop $49 \%$, double crop $42 \%$ and treble crop 9\%; cultivable land under irrigation $47 \%$. Value of land the market value of the land of the first grade is approximately Tk 7500 per 0.01 hectare. Main crops paddy, wheat, patal, karalla and varieties of dal (pulse). Extinct or nearly extinct crops Liseed, sesame, mustard seed, aus paddy, kaun, and watermelon. Main fruits Mango, Jackfruit, Litchi and bel (Wood apple).

\section{Location and site selection}

Godagari is an Upozila of Rajshahi District in the Division of Rajshahi, Bangladesh. This is the place where Mahananda River falls to Padma or Ganges. Godagari Upozilla is located at $24.466^{\circ} \mathrm{N} 88.33^{\circ} 6^{\circ} \mathrm{E}$. Rajarampur Pond and Shantospur pond has been created at Rajarampur village that is the north -West part of the Godagari, upazilla in Rajshahi district; from the statement of old man it is known that, most of the portion of the natural pond was under the illegal possession of local people though its position has in the map of Godagari. Basically the pond was only the water storage reservoir in Rajarampur (Figure 1).

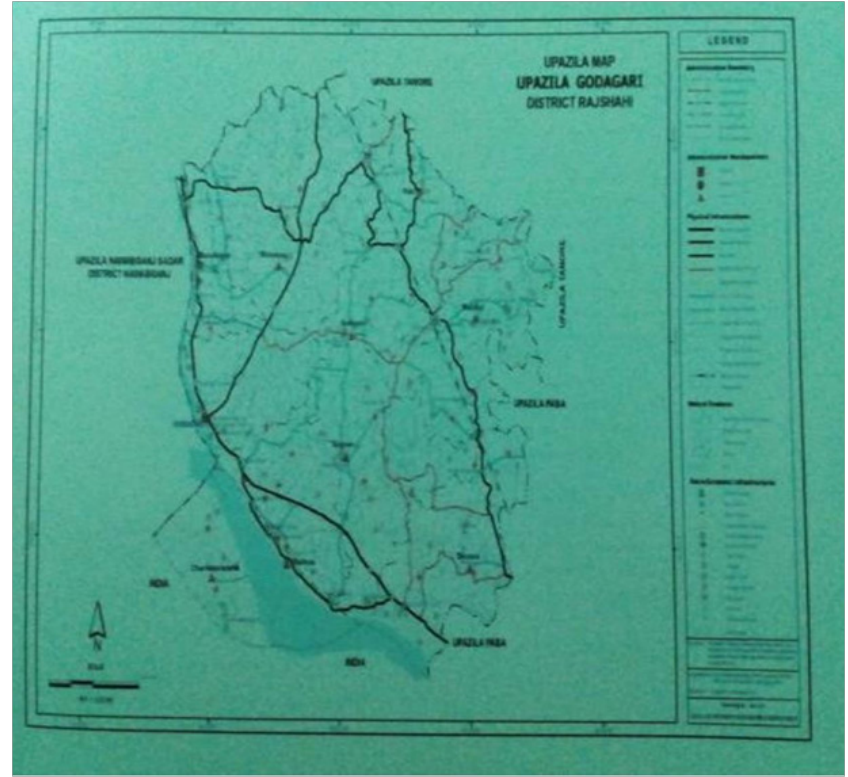

Figure I location of Godagari.

\section{Layout plan of pipe line Rajarampur and Shantospur pond project}

Shows in Figure 2.

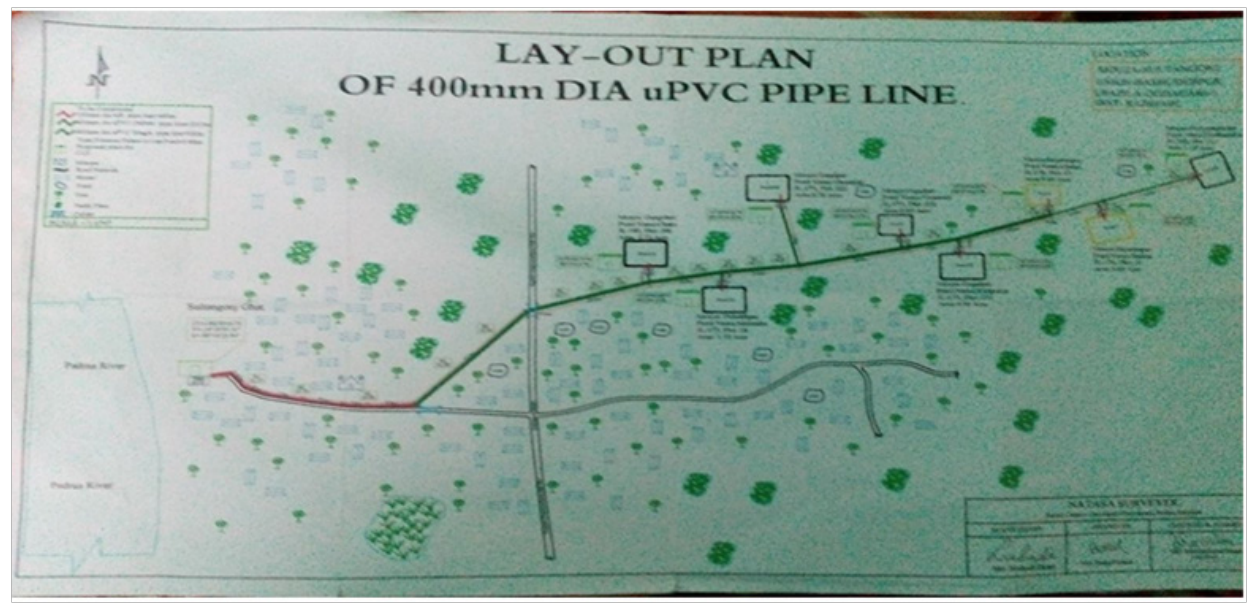

Figure 2 Layout pipe line.

\section{Overview picture of Barind land and forestation near the pond project area}

Shows in Figure 3.

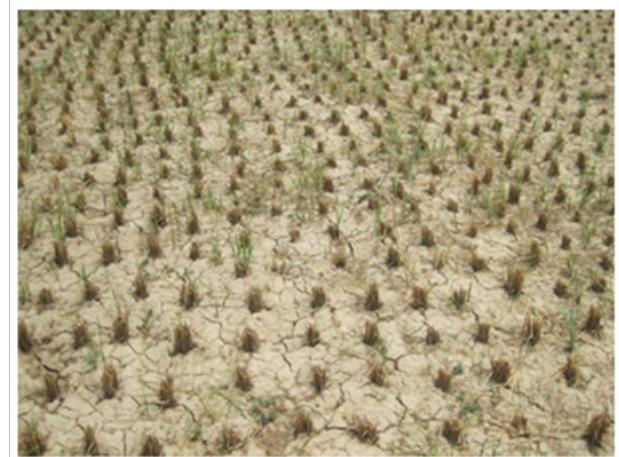

(a)

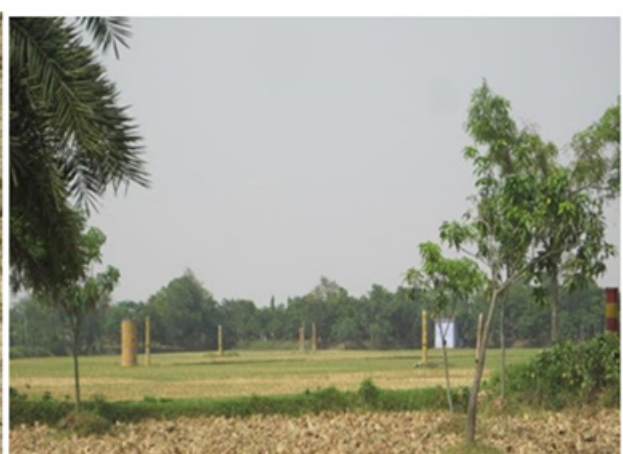

(b)

Figure 3 (a) Barind Land and (b) forestation near pond project.

Citation: Rahman R, Hossain M, Islam S. Study on surface water resources (river and pond) and their effects on agriculture at Godagari area, Rajshahi. Int J Hydro. 20I9;3(2):100-105. DOI: 10.15406/ijh.2019.03.00I70 


\section{View of Padma river in different seasons of year}

Shows in Figure 4.

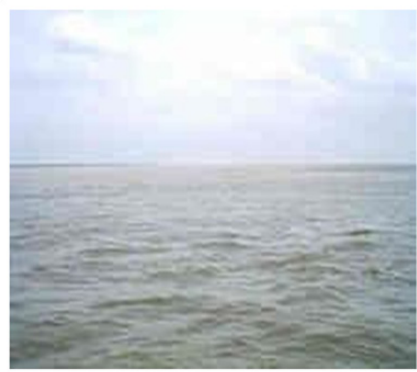

(a)

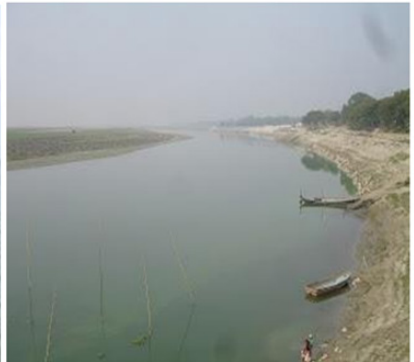

(b)

Figure 4 (a) View of Padma river in peak season; (b) View of Padma river in dry season.

\section{View of Mohananda river in different seasons of year}

Shows in Figure 5.

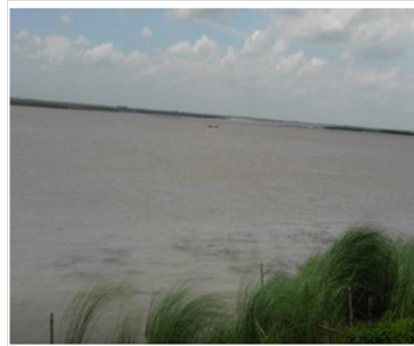

(a)

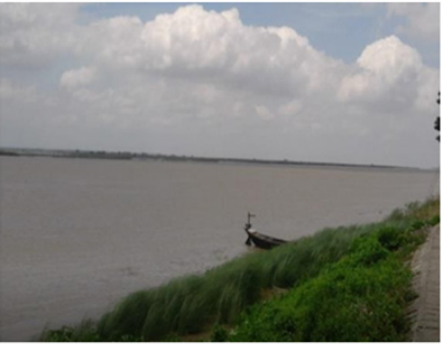

(b)

Figure 5 (a) View of Mananda river in peak season (b)View of Mahanda river in dry season.

\section{Objective of study}

a. To study the water resources within the planning area to enhance the natural resource values.

SHANTOSPUR POND
$* \quad$ The pond is situated at the kanaipur village in the union of
Godagar
$* \quad$ JL No 185
$* \quad$ Dag No 66
$* \quad$ Length of the pond is $56 \mathrm{~m}$
$* \quad$ Width of the pond is $53 \mathrm{~m}$
$* \quad$ Depth of the pond (From G.L) is $2.5 \mathrm{~m}$
$* \quad$ Area of the pond is 1.25 acre
$* \quad$ Amount of excavated land is $5948 \mathrm{~m}$
$* \quad$ Cost of excavation is 535320 taka
$* \quad$ The capacity of the pond is $8900 \mathrm{~m}$
$* \quad$ Total amount of irrigated land is 65 acre
$* \quad$ Annual crop production is $330 \mathrm{M}$.Ton

b. To analyze the collected data and find out socioeconomic acceptability of the project.

c. To analyze the water level and discharge of Padma and Mahananda river within the planning area.

d. To analyze the change of agricultural conditions of the study area.

\section{Methodology}

i. To learn about the current water resources condition.

ii. To learn about the flood information like flood inundation.

iii. To learn about the alignment of the ponds.

iv. To learn about the water collection system in ponds.

v. To see the water storage system in ponds.

vi. To see method of water distribution system to the nearby lands.

vii. To measure the length, breadth and height of ponds.

viii. To observe the physical properties of pond water (Figure 6).

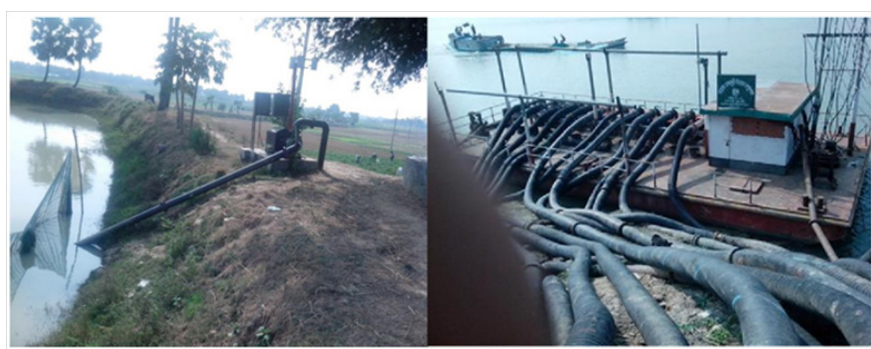

(a)

(b)

Figure 6 (a) Distributing water from pond for irrigation; (b) View of floating Pontoon on the river Padma at about $2.80 \mathrm{Km}$ away from the pond project

\section{Pond project at a glance}

Shows in Figure 7.

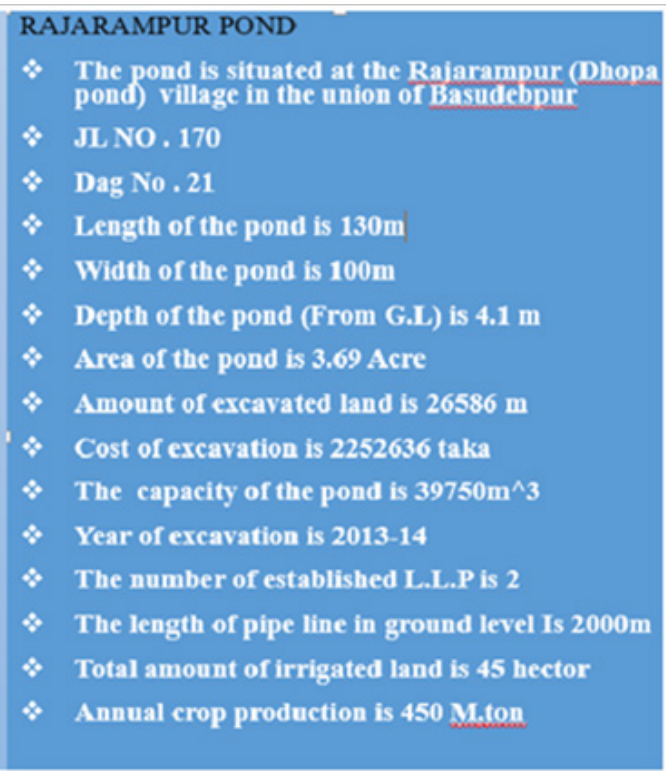

Figure 7 overview of pond at a glance. 


\section{Data collection}

The water level and discharge of Padma and Mahananda, data collected from BWDB (Bangladesh Water Development Board) Office of Rajshahi and Chapainawabganj. Agricultural data and environmental data collected from BMDA (Burind Multipurpose Development Authority) ${ }^{2}$ office of Godagari Upozilla and Rajshahi District, Rajshahi Agricultural office and from survey of ponds area

\section{Results}

\section{The variation of highest and lowest discharge of Padma River and mohananda river}

Shows in Figure 8.

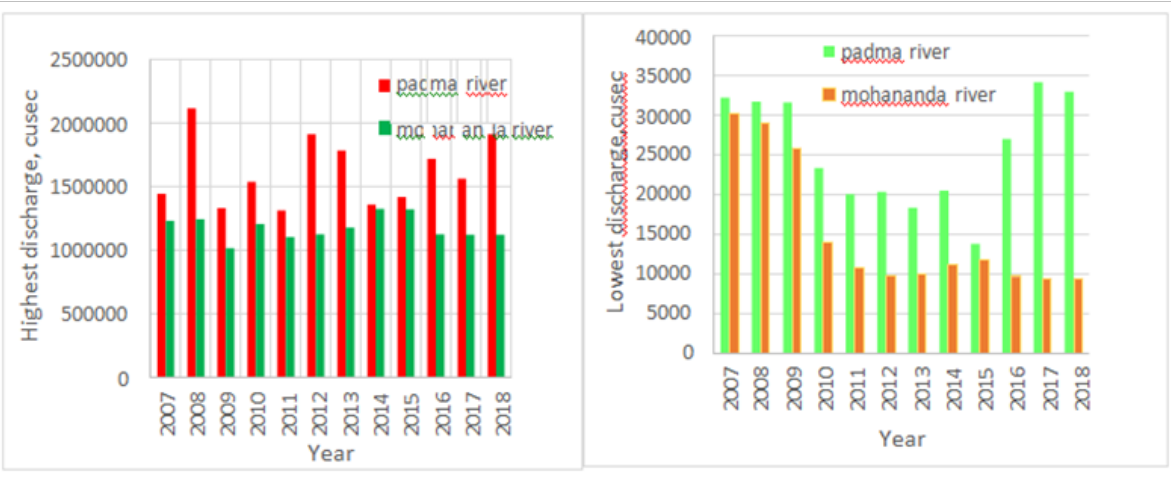

Figure 8 Highest and lowest discharge of Padma and mohananda river.

\section{Annual production of different crops in M.Tons/Hectare}

Shows in Figure 9.

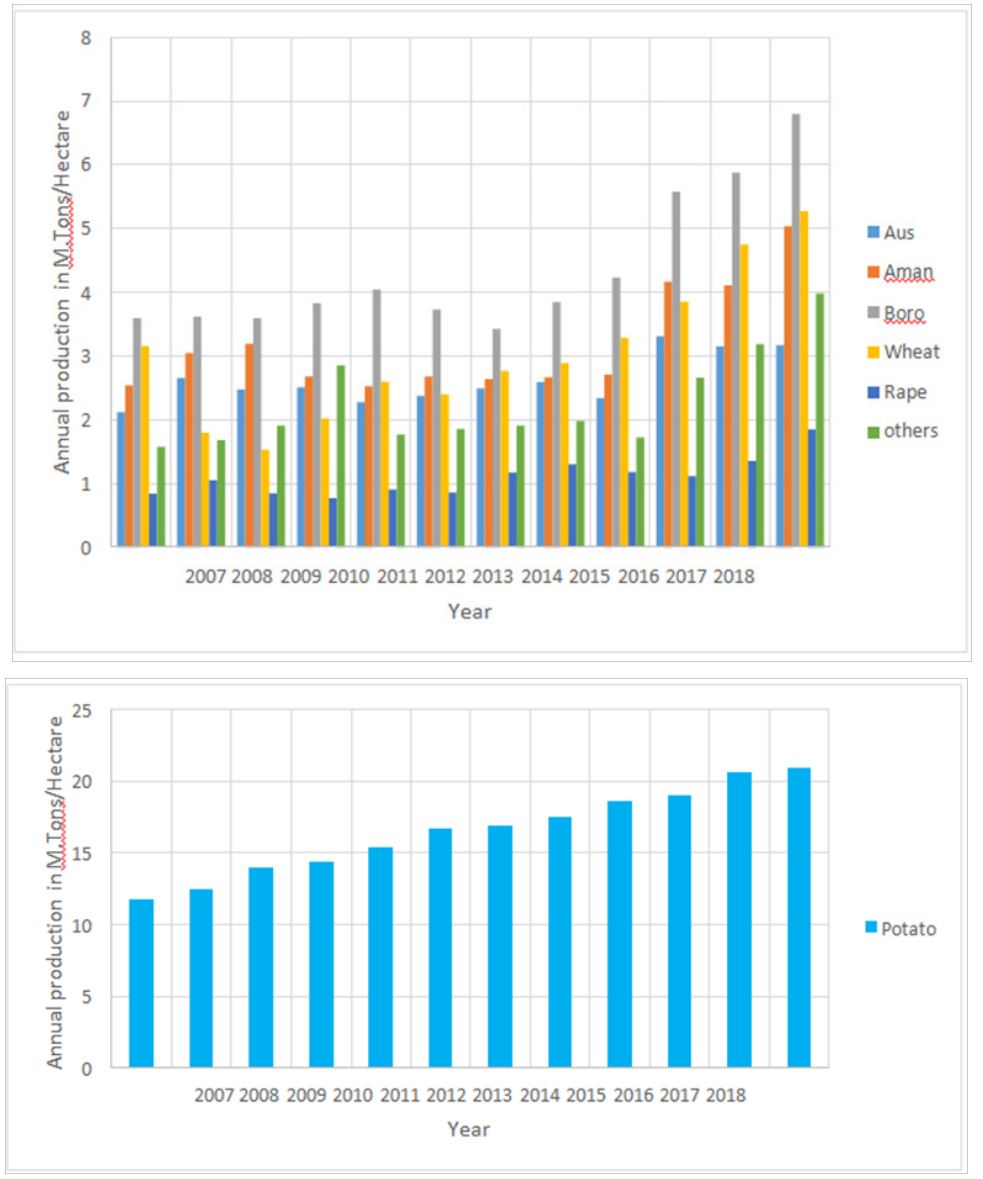

Figure 9 Chart of Annual production of different crops in M.Tons/Hectare.

Citation: Rahman R, Hossain M, Islam S. Study on surface water resources (river and pond) and their effects on agriculture at Godagari area, Rajshahi. Int J Hydro. 20 I9;3(2):I00-I05. DOI: I0.I5406/ijh.2019.03.00I70 


\section{Production around the pond project (M.Tons/Hectare)}

Shows in Figure 10.

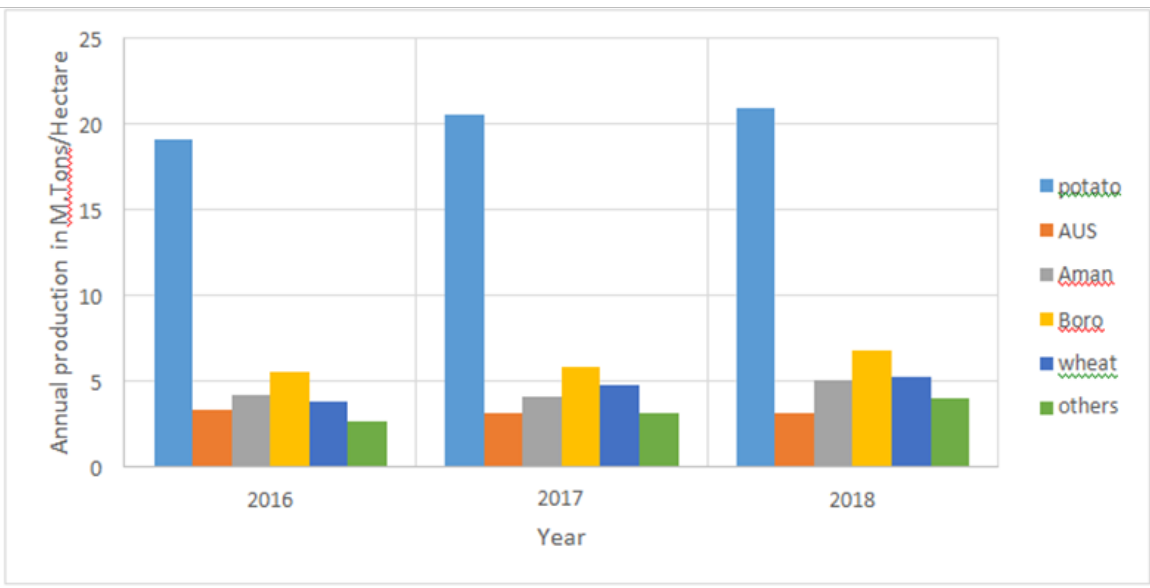

Figure 10 Annual production around the pond project of different crops in M.Tons/Hectare.

\section{Production around the others parts of area excluding pond project (M.Tons/Hectare)}

Figure 10 and Figure 11 are the comparision between the production of annual crops over the pond project and other parts of areas.It is clear that, the rate of growth of production is increased around the pond project.

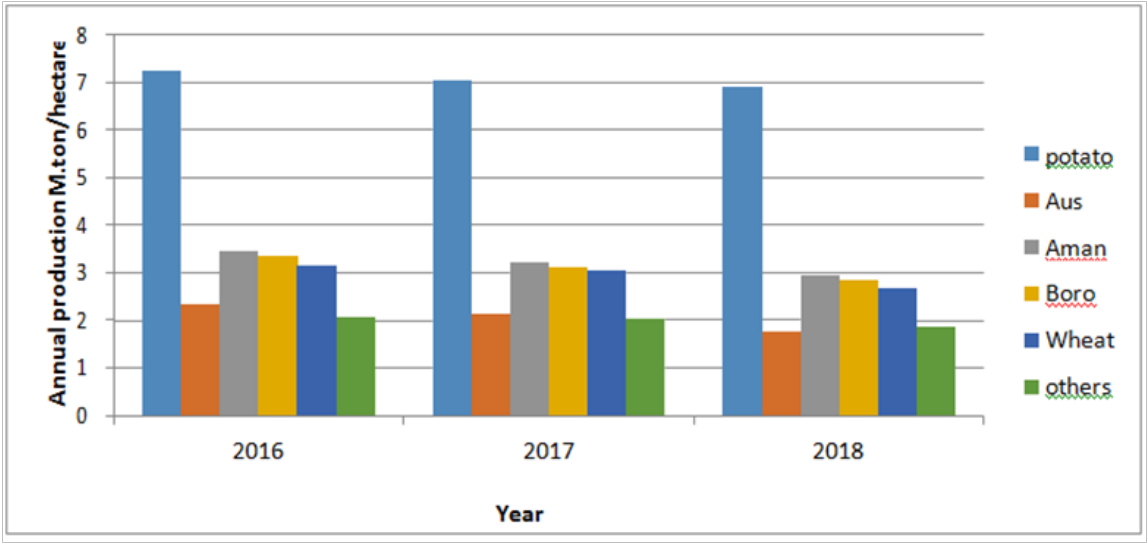

Figure I I Annual production of different crops outer parts of pond project in M.Tons/Hectare.

Total developments activities under various project of BMDA

Shows in Table 1.

Table I Total developments activities under various project of BMDA

\begin{tabular}{ll}
\hline Development activities & Achievement \\
\hline Installation of Deep Tube Well (DTW) & 13467 \\
Electrification of DTW (Nos.) & 12822 \\
Irrigation Water Distribution System (Nos.) & 12811 \\
Activating Inoperable DTW(Nos.) & 1973 \\
Construction of Cross Dam (Nos.) & 604 \\
Re-excavation of canals (KM.) & 1099 \\
Re-excavation of Derelict Ponds (Nos.) & 2878 \\
Digging of Dug Well (Nos.) & 47 \\
Feeder Road Construction (km.) & 747.68 \\
Drinking Water Supply from irrigation DTW (Nos.) & 1040 \\
\hline
\end{tabular}




\begin{tabular}{|c|c|}
\hline Development activities & Achievement \\
\hline A forestation (Lakh) & 237.48 \\
\hline Farmer Training (Person) & 116819 \\
\hline Deep tube well utilization in 20I0-20I I (No) & 12844 \\
\hline Irrigated area in $2010-201 \mathrm{I}(\mathrm{Hec})$ & Boro270064,T-Amon I50988\& Others 136199 \\
\hline Irrigation charge realization 2010-20II (Tk. Lakh) & 10828.26 \\
\hline Deep tube well utilization in 20I0-20I I (No) & 12297 \\
\hline Irrigated area in $201 \mathrm{I}-2012(\mathrm{Hec})$ & Boro-102967,T Amon I 68520 \& Others- 108956 \\
\hline Irrigation charge realization in 20I I-20I2 (Tk. Lakh) & 4267.28 \\
\hline
\end{tabular}

\section{Discussions on environment}

There are three basic part of environment that may have effect by pond project. It should have effect on temperature, relative humidity, weather and forestations. The result obtained from the data are discussed below.

\section{Temperature}

It is found that the maximum temperature has increased from $0.2^{\circ} \mathrm{C}$ to $2^{\circ} \mathrm{C}$. Due to the effect of pond project the temperature should be decrease but actually it is raised up. Due to the global warming the temperature has increased not only the project region but also in the whole world. As the rainfall was less in 2016 and 2017 the temperature could raise more, but the surface water and trees planted at every side of pond held to keep the temperature calm. On the other hand the average minimum temperature has decreased from $0.2^{\circ} \mathrm{C}$ to $1.5^{\circ} \mathrm{C}$.

\section{Relative humidity}

The data of relative humidity was available only from the year of 2017. In the year 2018 the rainfall was much lower resulting the relative decrease to its minimum condition to $61 \%$ in the month of March. In other times the relative humidity was on average level.

\section{Forestation}

In The Burind region it is still seen that the trees can't grow up due to lack of water. But at the side of pond as well as in the land at the side of pond a lots of trees has been planted by the BMDA as well as by the local people. The BMDA has planted 123 Nos. of trees on the side of the ponds. Local people are now encouraging to plant various trees like Mango, Guava, Jackfruits and other various trees which resulting a positive impact on natural environment. ${ }^{3-9}$

\section{Conclusion}

The discharge data of Padma river and mohanonda river (shows that in the year 2007 to 2018 the highest and lowest discharge. We have seen that the rate of highest and lowest discharge are much fluctuating. But for both the Padma and Mahananda river we have seen that the highest discharge occurs in the monsoon, when the river is filled by water where the lowest discharge occurs during the dry season. It is also seen that the highest and lowest water level of Padma and Mahananda river is decreasing in drought season and increasing a little bit in the rainy season or monsoon. For the construction of Farakka barrage the Padma is becoming desert in the drought season.
So, there must be an alternative way to store the water during rainy season for the use in the drought season. It is clear that under pond project the annual crops growth are increased compared to outer parts of the areas. As the various crops are in large quantity the land owners are also happy to harvest their land under pond the project. These production of large amount of various crops are contributing to develop the national GDP. Most of the young generation are now involved to grow various crops under this pond project to reduce unemployment.

\section{Acknowledgment}

None.

\section{Conflicts of interest}

The authors declare that there is no conflict of interest.

\section{References}

1. Mezanur Rahman, Shihab Uddin. Study on shormongla Canal and its impact on Ground water. Agriculture and Environment. Supervised by Prof Dr Shafi Uddin Miah. 2011.

2. Asaduzzaman. Director of Burind Multipurpose Development Authority (BMDA). Study on water resources of Padma and Mahananda and their impact on agricultural production over Rajshahi zone. 1998.

3. Shyamal kumar sen, Iftakher Hassain. Analysis of Drought in the Burind Tract. RUET, Rajshahi, Bangladesh. 2001.

4. Ashfakul Islam, Kamal Chandra Basak. Characterization of Droughts in North-Western region of Bangladesh and it impact on Agriculture. RUET, Rajshahi, Bangladesh. 1997.

5. Aditi Sharma. Spatial Data Mining for Drought Monitoring: an Approach using Temporal NDVI and Rainfall Relationship. International Institute for Geo-information Science and Earth Observation Enschede, the Netherlands and Indian Institute of Remote Sensing Agency (NRSA), Department of Space govt of India, Dehradun, India. 2006.

6. Garcia NO. Drought Analysis in Northeastern Argentine. Ciuded University, Santa, Argentina. 2005.

7. Maksudul Haque, Zillur Rahman. Analysis of Drought in the great Mymenshing. Rajshahi. Bangladesh. 2000.

8. Mirza Shakhawat Hossain, Moniruzzaman. Socio- Economic Acceptability and Economic Feasibility of North Rajshahi Irrigation Project. RUET, Rajshahi, Bangladesh. 1998.

9. Asim krisna Sajjan. Characterization of 1994-95 Droughts in Northwestern region of Bangladesh and its impact on Agriculture. BUET. Dhaka, Bangladesh. 1998. 